\author{
WIKTORIA GORNIG \\ Instytut Biologii Środowiskowej \\ Zakład Paleozoologii \\ Sienkiewicza 21, 50-335 Wrocław \\ E-mail: wiktoria.gornig@uwr.edu.pl
}

\title{
CZY TYRANOZAUR MIAŁ SKRZYDŁA? PIÓRA U NIEPTASICH DINOZAURÓW
}

\section{WPROWADZENIE}

Nie ma prawdopodobnie grupy prehistorycznych zwierząt wywołujących takie emocje, jak dinozaury. $Z$ tego zainteresowania korzystaja zarówno placówki naukowe i muzea, przyciagając rzesze spragnionych wiedzy entuzjastów, jak i przemysł filmowy, odzieżowy czy zabawkowy, komercjalizujacc pradawne gady. W związu $z$ tym pojawiają się rozmaite interpretacje dotyczace prawdopodobnego wyglacdu tych mezozoicznych krewniaków ptaków. Najbardziej rozpowszechnionym i zakorzenionym wyobrażeniem sa oczywiście pokryte łuskami, zębate potwory, wygladajace po prostu "gadzio”.

Celem niniejszego artykułu jest zaprezentowanie obecnego stanu wiedzy dotyczacej pokrycia ciała dinozaurów piórami, ze szczególnym uwzględnieniem jednego $z$ najsłynniejszych przedstawicieli grupy, tyranozaura (Tyrannosaurus rex).

\section{SYSTEMATYKA DINOZAURÓW}

Dinozaury stanowia dużą, monofiletyczna grupe archozaurów (Archosauria) i pozostaja najlepiej rozpoznawalnymi przedstawicielami kladu. Sa blisko spokrewnione $z$ żyjacymi dziś krokodylami i $Z$ wymarłymi pterozaurami. Powstały w triasie jako pierwotnie dwunożne zwierzęta $z$ chwytna dłonią. Od początku jury gwałtownie różnicowały się, tworząc mnogość form i gatunków. Powszechnie dinozaury dzielimy na dwie grupy: dinozaury ptasiomiedniczne (Ornithischia) oraz gadziomiedniczne (Saurischia). Mimo że zgodnie $z$ nazewnictwem podział ten opiera się m.in. na budowie miednicy, zdaniem większości badaczy odzwierciedla on rzeczywiste pokrewieństwo między przedstawicielami każdej $z$ tych grup. Dinozaury ptasiomiedniczne były w większości dużymi, nierzadko uzbrojonymi i mocno wyspecjalizowanymi roślinożercami, dinozaury gadziomiedniczne obejmowały gigantyczne długoszyje zauropody (Sauropoda) i drapieżne teropody (Theropoda) (Ryc. 1). O tych ostatnich można powiedzieć, że w sensie filogenetycznym żyją do dziś - ich potomkami sa ptaki (BENTON 2004). W ostatnich latach pojawiły się również alternatywne hipotezy dotyczace klasyfikacji dinozaurów, łaczace ze soba teropody i dinozaury ptasiomiedniczne w klad Ornithoscelida (BARON i współaut. 2017), ale do ich ostatecznego potwierdzenia lub wykluczenia potrzebne sa dalsze badania i analizy.

\section{SKĄD SIE CIORĄ PIÓRA?}

Pióra stanowią najbardziej skomplikowane pokrycie ciała wśród kręgowców i obecnie występuja tylko u ptaków. Wyróżnia się wiele typów piór, które w zależności od budowy i miejsca występowania spełniaja rozmaite funkcje: lotne, termoizolacyjne, pokazowe, a nawet dotykowe (PRUM 1999, STETTENHEIM 2000, PRUM i BRUSH 2002).

Niewiele wiadomo na temat dokładnego pochodzenia piór i dziś można się tylko domyślać, jaka pierwotna funkcję miały spełniać. Istnieje kilka hipotez: wyewoluowały, aby pomóc utrzymać stała temperaturę ciała, chroniły przed woda, miały pełnić funkcje pokazowe lub dotykowe. Starsza i swego czasu niezwykle popularna hipoteza, mówią- 


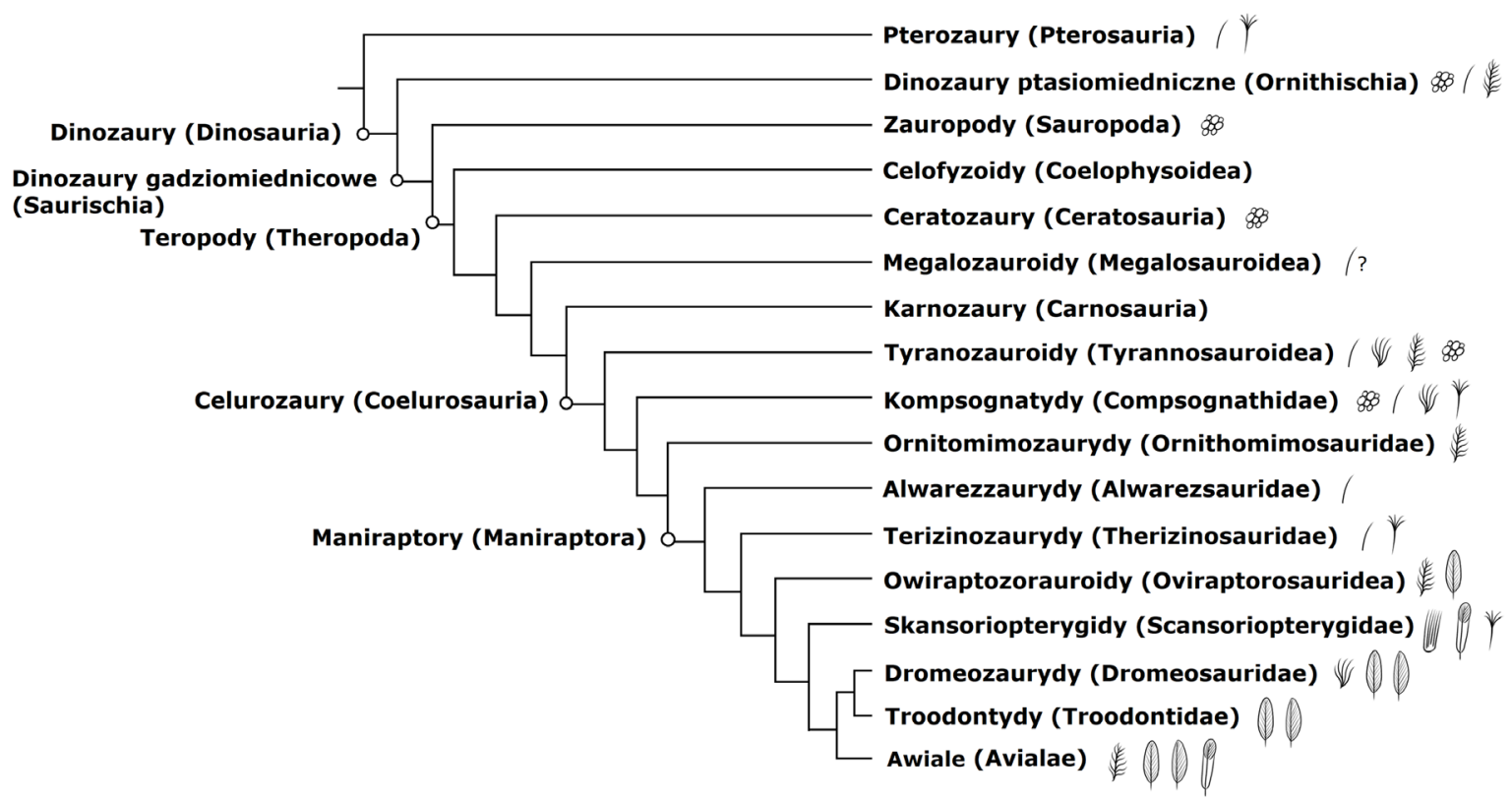

Dotychczas odkryte struktury okrywające ciała pterozaurów,

dinozaurów ptasiomiednicznych i dinozaurów gadziomiednicznych

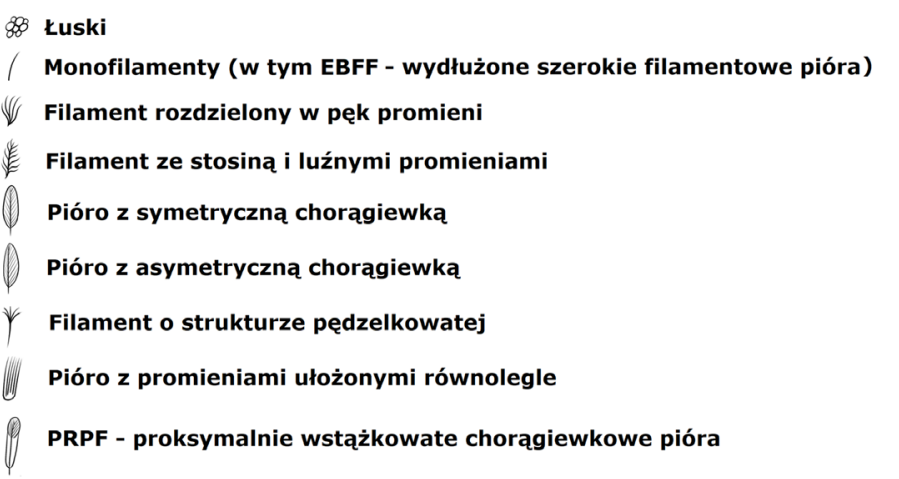

Ryc. 1. Uproszczone drzewo filogenetyczne dinozaurów z uwzględnieniem grupy siostrzanej pterozaurów. W ramce poniżej wymienione sa odkryte dotychczas struktury pokrywajace ciała zwierząt (wg BENTON 2004, BARETT i współaut. 2015, WANG i współaut. 2019).

ca o pierwotnej funkcji lotnej, w świetle najnowszych badań wydaje się już być nieaktualna (PRUM i BRUSH 2002).

W proponowanym przez PRUMA (1999) rozwoju ewolucyjnym piór można wyodrębnić kilka stadiów. Stadium pierwsze to monofilament pozbawiony jakichkolwiek rozgałęzień, pusty w środku. Stadium drugie to filament rozdzielony na pęk promieni wyrastajacych $z$ jednej dutki. Stadium trzecie to najbardziej zagadkowy etap - dokonało się tutaj przekształcenie, którego natura nie jest jasna. Możliwe, że najpierw wytworzyla się stosina $z$ odchodzacymi od niej luźno promykami lub najpierw powstały promyki (jeszcze przed powstaniem stosiny). Nowe badania molekularne wspierają pierwsza możliwość i dodatkowo sugeruja, że dwu- bocznie symetryczne pióro ze stosina jest bardziej zaawansowane niż promieniście symetryczna struktura (Xu i GuO 2009). Typowe ptasie pióro $z$ symetryczną choragiewka oraz zróżnicowanymi promykami i haczykami należy do stadium czwartego. Ostatni etap, stadium piąte, to modyfikacje $\mathrm{w}$ strone asymetryczności. W odniesieniu do dinozaurów, wcześniejsze stadia często nazywa się w literaturze protopiórami.

Proponowany model wspierają obserwacje rozwoju piór współczesnych ptaków oraz fakt, że wszystkie pięć stadiów możemy zaobserwować u wymarłych już nieptasich dinozaurów. (PRUM 1999, PRUM i BRUSH 2002, CHANG i współaut. 2009, YANG i współaut. 2018) 
Pióra sa dość wytrzymałymi strukturami, ale rzadko ulegaja fosylizacji. Niemniej ich odciski sa znajdowane w niektórych typach drobnoziarnistych skał, m.in. w wapieniach czy cieniutkich łupkach (NORELL i XU 2005). Pióra znane sa także $z$ mezozoicznych bursztynów (ScHLEE 1973, XING i współaut. 2016).

\section{PIÓRA U TEROPODÓW}

Nie mamy w tej chwili żadnych watpliwości, że wiele nieptasich teropodów było opierzonych. Sa na to liczne bezpośrednie dowody. Wśród nich między innymi: odciski w skałach (XU i współaut. 1999, 2003), ślady przyczepu piór na kościach łokciowych (TURNER i współaut. 2007, DEPALMA i współaut. 2015, FUnSTON i CURRIE 2016), wykształcenie pygostylu (zrośniętych kręgów ogonowych), na którym oparte sa pióra (LEE i współaut. 2014), a nawet tak spektakularne znaleziska, jak opierzony ogon młodocianego dinozaura zachowany $\mathrm{w}$ bursztynie (XING i współaut. 2016). W niektórych przypadkach skamieniałości sa tak dobrze zachowane, że można zaobserwować i zbadać tak drobne struktury jak melanosomy, co z kolei umożliwia poznanie kolorystyki wymarłych gadów (LI i współaut. 2010, 2012; ZHANG i współaut. 2010). Melanosomy to niewielkie organella, które występuja w komórkach zwanych melanocytami i produkuja barwnik melaninę (VINTHER i współaut. 2008). Najwięcej skamieniałości o tak dobrym stanie zachowania pochodzi $z$ chińskiej prowincji Yixian.

Pierwsze znane nauce pióra zachowane w materiale kopalnym należą do słynnego praptaka archeopteryksa (Archaeopteryx lithographica) odkrytego w 1861 r. Zwierzę to miało na ciele kilka typów piór, w tym zaawansowane asymetryczne lotki stadium piątego występujące na ogonie i kończynach, tworzace skrzydła. Występowały one także na kończynach dromeozaurydów (Microraptor, Zhenyuanlong) oraz na ogonach niektó-

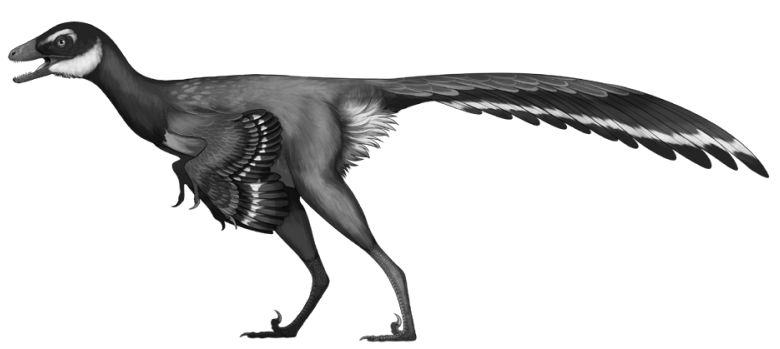

Ryc. 2. Jinfengopteryx elegans, upierzony przedstawiciel troodonów - zaawansowanych nieptasich dinozaurów (rys. W. Gornig). rych troodonów (Jianianhualong) (NORELL i XU 2005, LÜ i BRUSATTE 2015, XU i współaut. 2017).

Struktury $z$ symetrycznymi choragiewkami występowały między innymi na ogonach i przednich kończynach owiraptorozauroidów (Caudipteryx, Similicaudipteryx, Protarcheopteryx), na ogonach niektórych dromeozaurydów (Changyuraptor) i troodontydów (Jinfengopteryx) (Ryc. 2), czy obu parach skrzydeł bazalnych eumaniraptorów (Anchiornis) (HAN i współaut. 2014, XU i GUO 2009).

Protopióra stadium trzeciego wykazano na ciele należącego do kompsognatydów Sinosauropteryx, na przednich kończynach należącego do ornitomimozaurydów Ornithomimus, u owiraptorosauroidów (Caudipteryx, Protaercheopteryx), a także najprawdopodobniej u prymitywnego tyranozauroida Dilong (XU i współaut. 2010, ZELENITSKY i współaut. 2012).

Pozbawione stosiny pęczki promieni (stadium 2) występowały m.in. u kompsognatydów (Sinosauropteryx, Sinocalliopteryx), tyranozauroidów (Dilong, Yutyrannus) czy dromeozaurydów (Sinornithosaurus) (Ji i współaut. 2007, XU i współaut. 2010).

Nierozgałęzione monofilamenty (stadium 1) wystepuja zarówno u bardziej zaawansowanych celurozaurów takich jak alwarezzaurydy (Shuvuuia), jak i mniej zaawanowanych teropodów, jak Sciurumimus o niepewnej pozycji systematycznej (SCHWEITZER i współaut. 1999, XU i GUO 2009, RAUHUT i współaut. 2012). Niezwykłe struktury tego stadium (ang. elongated broad filamentous feathers, EEBF; wydłużone szerokie filamentowe pióra) prezentowały także terizinozaurydy. U wczesnokredowego Beipiaosaurus inexpectus (Ryc. 3) na głowie, szyi i przednich kończynach znajdowały się długie i sztywne protopióra o prawdopodobnej funkcji wizualnej (XU i współaut. 2009). Podobne elementy odnaleziono na grzbiecie nieco młodszego Jianchangosaurus yixianensis (PU i współaut.

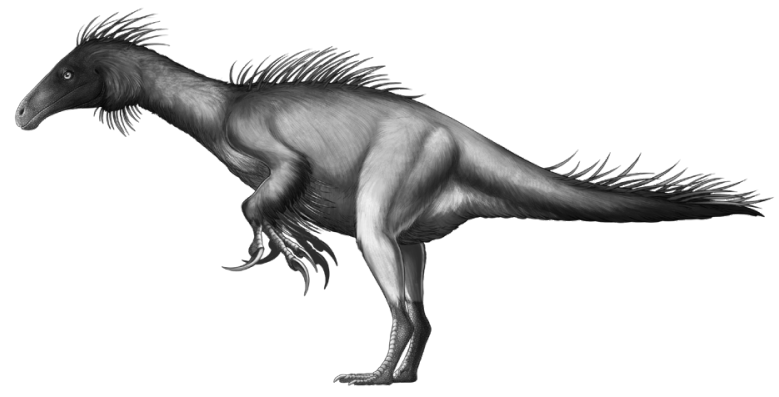

Ryc. 3. Beipiaosaurus inexpectus - długie "kolce” na głowie, grzbiecie, kończynach i ogonie to protopióra typu EEBF (rys. W. Gornig). 
2013), a być może nawet u tyranozauroidów i kompsognatydów (XU i współaut. 2010).

Najbardziej bazalnym teropodem, u którego na pewno obserwujemy pióra, jest wspomniany Sciurumimus albersdoerferi znaleziony w osadach późnej jury. Jego nazwa oznacza „udajacy wiewiórkę" i odnosi się do długiego, pokrytego puszystymi protopiórami ogona, który rzeczywiście może przypominać tę samą część ciała wiewiórek. Pióra były prostej budowy, nierozgałęzione, przypominajace stadium 1 ich ewolucji (RAUHUT i współaut. 2012). Sciurumimus jest gatunkiem o niepewnej pozycji systematycznej między innymi dlatego, że jedyne znane szczątki należa do osobnika młodocianego. Badacze klasyfikuja go albo jako bazalnego celurozaura (GODEFROIT i współaut. 2013) albo wręcz jako przedstawiciela prymitywniejszych megalozauroidów (RAUHUT i współaut. 2012, 2018).

\section{ZRÓŻNICOWANIE UPIERZENIA TEROPODÓW}

Oprócz piór odpowiadających swoim wyglądem poszczególnym stadiom rozwojowym proponowanym przez PRUMA (1999), w materiale kopalnym znajduja się także struktury, które różnią się od tych proponowanych w modelu. Protopióra pędzelkowate, składajace się $z$ pojedynczej osi, rozgałęzione promieniście wyłacznie na samym końcu pokrywały m.in. ciała Sinornithosaurus, Beipiaosaurus czy Yi (XU i współaut. 2009, 2015). U niektórych grup bardzo wczesnych ptaków (Confuciusornithiformes, Enanthiornithes) oraz niektórych skansoriopterygidów (jak Epidexipteryx) stwierdzono wystepowanie unikatowych wstażkowatych piór na ogonie (ang. proximally ribbon-like pennaceous feathers, PRPF; proksymalnie wstażkowate choragiewkowe pióra). Pióra te miały niezróżnicowaną na promienie część proksymalną, natomiast na końcach wykazywały typowa, choragiewkową strukturę (O'CONNOR i współaut. 2012). U Epidexipteryx potwierdzono także występowanie innego rodzaju elementów, gdzie promienie ułożone były równolegle do siebie i wyrastały ze wspólnej, membranopodobnej struktury (ZHANG i współaut. 2008).

Wiele opierzonych celurozaurów, szczególnie tych bardziej zaawansowanych, było pokrytych rozmaitymi typami piór, podobnie jak u dzisiejszych ptaków (MARTYNIUK 2012). Wykazano także różnice w upierzeniu między osobnikami juwenilnymi i dorosłymi. Przednie kończyny młodych Ornithomimus edmontonicus pozbawione były dużych piór na, które występowały u osobników dorosłych. Pióra te mogły odgrywać jakąś rolę w życiu dorosłego osobnika, np. w godach (ZELENITSKY i współaut. 2012). Również młodociane Similicaudipteryx yixianensis miały inne pióra niż osobniki dorosłe. Między innymi brakowało im drugorzędowych lotek, a pierwszorzędowe były znacznie krótsze niż te, które znajdowały się u przedstawicieli w pełni dojrzałych (XU i współaut. 2010).

Ciekawym, prawdopodobnym zjawiskiem jest także występowanie różnego typu pokryć na różnych częściach ciała. Taka sytuacja może występować u późnojurajskiego kompsognatyda Juravenator starki. Dolna część ogona tego dinozaura była pokryta łuskami, natomiast górna najprawdopodobniej prostymi filamentami (GöHLICH i CHIAPPE 2006, CHIAPPE i GÖHLICH 2010).

Wiele nieptasich celurozaurów miało tzw. pennibrachia, czyli przednie kończyny $z$ długimi piórami o budowie skrzydła, ale niesłużace do lotu czy szybowania (SulLIVAN i współaut. 2010). Najwcześniejsze pojawiły się u ornitomimozaurydów; składały się $Z$ prostych piór o niepołaczonych promykami choragiewkach i najprawdopodobniej dobrze sprawowały się w rytuałach godowych (ZELENITSKY i współaut. 2012). U terizinozaurydów pennibrachia tworzone były przez wydłużone szerokie filamentowe pióra (XU i współaut. 2009). U owiraptorozaurów złożone były już z dobrze wykształconych, symetrycznych piór. Warto wspomnieć, że wiele szczątków tych zwierzat znajdowano w gnieździe w charakterystycznej siedzacej pozycji $z$ przednimi kończynami rozłożonymi na boki, co sugeruje wysiadywanie jaj i osłanianie ich za pomocą długich piór (FUNSTON i CURRIE 2016). Część niewielkich dromeozaurydów miała dobrze rozwinięte skrzydła, które umożliwiały szybowanie, a w przypadku Microraptor być może nawet lot (DECECCHI i współaut. 2016). U innych (Velociraptor, Dakotaraptor) wystepuja charakterystyczne guzki na kości łokciowej, wskazujace na występowanie mocnych lotek, pomimo faktu, że zwierzęta te były stosunkowo duże i lokomocja w powietrzu była u nich wykluczona. Najprawdopodobniej guzki te stanowiły pozostałość po niedużych szybujacych/latajacych przodkach. Ich potomkowie (Velociraptor, Dakotaraptor) używali pennibrachiów np. do stabilizacji pozycji ciała przy polowaniu, ochrony młodych czy wysyłania sygnałów wizualnych, zarówno agonistycznych, jak i antagonistycznych (DEPALMA i współaut. 2015, TURNER i współaut. 2007).

Warto wspomnieć, że u części dinozaurów skrzydła występowały zarówno na kończynach przednich, jak i na tylnych. Dotyczyło to kilku bazalnych eumaniraptorów (Anchiornis), bazalnych awiali (Sapeornis, Pedopenna) i niektórych bazalnych dromeozau- 
rów (Microraptor, Changyuraptor) (ZHENG i współaut. 2013, HAN i współaut. 2014).

Niektórzy badacze nie zgadzają się $z$ tym, że ślady filamentów niektórych prymitywniejszych celurozaurów (Sinornithosaurus czy Dilong) sa faktycznie protopiórami, a pozostawione w skałach odciski interpretuja raczej jako pozostałości po włóknach kolagenowych (LiNGHAM-SOLIAR i współaut. 2007). Zważywszy jednak na to, że ślady struktur sa stosunkowo duże w porównaniu do tych, które pozostawiaja kolagenowe włókna, ułożone podobnie jak pióra współczesnych ptaków i dodatkowo zawieraja ślady melanosomów, można $z$ dużym prawdopodobieństwem uznać, że sa to jednak pozostałości protopiór (XU i współaut. 2010).

Protopióra $z$ cała pewnością pojawiły się u przodka celurozaurów. Wśród innych grup teropodów (Coelophysoidea, Ceratosauria, Carnosauria oraz Megalosauroidea, jeżeli wykluczymy Sciurumimus) dotychczas nie odnaleziono śladów tego typu pokrycia. Co więcej, istnieja odciski ich łusek. Należy przy tym mieć na uwadze, że pióra sa strukturami, które moga się w materiale kopalnym nie zachować lub zostać niechcacy pominięte przez badaczy (BARRETT i współaut. 2015).

\section{PIÓRA U DINOZAURÓW PTASIOMIEDNICZNYCH (I NIE TYLKO)?}

Wśród dinozaurów nie tylko teropody mogły mieć pióra i protopióra. Niektórzy naukowcy upatruja tych struktur u dinozaurów ptasiomiednicznych. Kulindadromeus zabaikalicus żyjący w środkowej jurze był jednym $z$ najbardziej niezwykłych przedstawicieli tej grupy. Jego głowę, szyję i tułów pokrywały struktury niezwykle podobne do piór stadium 1. W obszarach ramienia i uda miał natomiast struktury przypominajace stadium 3. Dodatkowo, na jego łydkach znaleźć można wyjątkowe, wstążkopodobne elementy, nieprzypominające żadnych $z$ występujących dziś piór. Reszta ciała zwierzęcia (dolne części kończyn i ogon) pokryta była zróżnicowanymi łuskami (GODEFROIT i współaut. 2014). Tianyulong confuciusi był późnojurajskim heterodontozaurem (LIU i wspó1aut. 2012) znalezionym $w$ formacji Yixian (prowincja Liaoning). Jego grzbiet pokryty były stosunkowo długimi, nierozgałęzionymi, włóknistymi filamentami (ZHENG i współaut. 2009). Podobne struktury znaleziono u występujacego we wczesnej kredzie na podobnym obszarze Psittacosaurus. U tego gatunku rząd długich na około 16 centymetrów, sztywnych i grubych filamentowych wytworów występował tylko w proksymalnej części ogona. W związku $z$ tym wyklucza się termoregulacyjne funkcje tych struktur (nie okrywaja całego ciała zwierzęcia). Najbardziej prawdopodobne jest, że mogły one pełnić funkcje pokazowe (np. podczas godów). Poza tym całe ciało Psittacosaurus było pokryte łuskami (MAYR i współaut. 2002).

Sięgając nieco dalej i już poza grupe dinozaurów, spokrewnione $z$ nimi pterozaury (Pterosauria) również charakteryzowały się niezwykłym pokryciem ciała, tak zwanymi pyknofibrami (ang. pycnofibers). Były to filamentowe struktury zarówno pojedyncze, jak i rozgałęziające się, przypominającymi stadia 1 i 2 rozwoju ewolucyjnego piór. Struktury różniły się morfologia $\mathrm{w}$ zależności od tego, na której części ciała występowały (WANG i współaut. 2002, YANG i współaut. 2018).

\section{POTENCJALNA HOMOLOGIA?}

Nie wiadomo, czy pióra teropodów i filamentowe struktury występujace na ciałach dinozaurów ptasiomiednicznych i pterozaurów sa homologiczne. Jeżeli tak, znaczyłoby to, że struktury te pojawily się już we wczesnym triasie, jeszcze przed rozdzieleniem się wszystkich linii. Naukowcy pod tym względem zachowuja jednak duża dozę sceptycyzmu (NORELL i XU 2005, BARRETT i współaut. 2015).

Zostało zauważone, że filamentowe struktury u Psittacosaurus i Tianyulong różnią się morfologia od protopiór teropodów. Potencjalna homologia $z$ protopiórami jest możliwa, ale prawdopodobne jest także, że elementy te sa mocno przekształconymi łuskami (MAYR i współaut. 2002, BARRETT i współaut. 2015). Z kolei duże zróżnicowanie filamentów pterozaurów może być potwierdzeniem homologii tych struktur u wszystkich trzech grup (YANG i współaut. 2018). U zauropodów jednak do tej pory nie wykazano żadnych elementów, które mogłyby być homologiczne $z$ piórami. Istnieja natomiast dowody, że ich skóra była pokryta łuska$\mathrm{mi}$, nawet $\mathrm{w}$ stadium embrionalnym (CORIA i CHIAPPE 2007). Także u bardziej prymitywnych teropodów, takich jak np. ceratozaury, próżno szukać protopiór (XU i GUO 2009). Oczywiście wciąz istnieje prawdopodobieństwo, że łuski mogły ulec redukcji np. w zwiąku $z$ dużymi rozmiarami.

Należy również zwrócić uwage na fakt, że nie dysponujemy zbyt bogata kolekcja odcisków skóry dinozaurów i taksonów pokrewnych $z$ czasów, kiedy następowało ich najbardziej kluczowe różnicowanie się. Nie ma żadnych odcisków $z$ okresu późnego triasu (znaleziono jedynie tropy), a te $z$ okresu wczesnej i środkowej jury sa bardzo rzadkie (BARRETT i współaut. 2015). Większość znanych nam odcisków potencjalnego pokrycia 


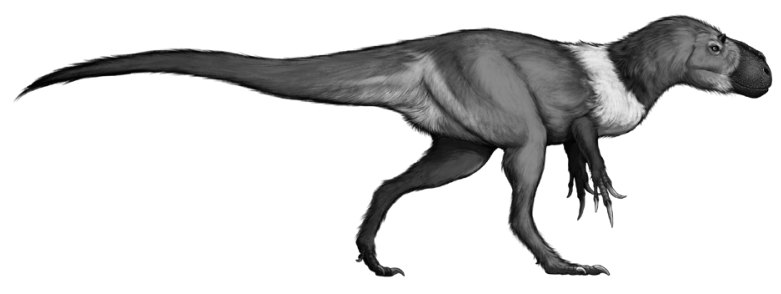

Ryc. 4. Przedstawienie dorosłego osobnika gatunku Yutyrannus huali. Zwierzę to dorastało do 9 metrów długości i było w całości pokryte prostymi protopiórami (rys. W. Gornig).

ciała pochodzi z górnej jury i kredy, kiedy większość głównych grup dinozaurów była już wykształcona i żyły także pierwsze ptaki. Najwcześniejsze znane odciski pokrycia ciała pterozaurów również pochodza $z$ przełomu środkowej i górnej jury (YANG i współaut. 2018). Pozostaje jedynie czekać na dalsze odkrycia i badania, które moga rozwiazać zagadkę pokrycia ciała mezozoicznych gadów.

\section{KRÓL-TYRAN - W PIÓRACH CZY W ŁUSKACH?}

Ponieważ w tytule niniejszej pracy odwołano się do najsłynniejszego mezozoicznego drapieżnika, tyranozaura (Tyrannosaurus rex), warto omówić, jak wyglacdało pokrycie jego ciała w swietle wszystkich dostępnych nam informacji.

Tyranozauroidy (Tyrannosauroidea) to grupa zaawansowanych i drapieżnych teropodów, które żyły na terenach Ameryki Północnej i Eurazji. Znane sa od środkowej jury; wiadomo też, że przetrwały aż do samego wymierania kredowego. Charakteryzuja się wyspecjalizowanym uzębieniem. W obrębie linii można zaobserwować trend na powiększanie rozmiarów ciała i redukcji przednich kończyn. W obrębie grupy znajduje się zaawansowana rodzina tyranozaurydów (Tyrannosauridae), do której należy Tyrannosaurus rex (HOLTZ 2004, CURRIE i współaut. 2003, Xu i współaut. 2004).

Dilong paradoxus to dość prymitywny przedstawiciel tyranozauroidów, znany $z$ wczesnej kredy $z$ formacji Yixian (zachodni Liaoning, Chiny). Był stosunkowo mały (największy znany osobnik mierzył 1,6 metra długości), $z$ długim pyskiem i (jeszcze) trójpalczastymi dłońmi. Dilong był wyjatkowym tyranozauroidem, pod tym względem, że całe jego ciało pokryte było prostymi protopiórami (XU i współaut. 2004). Mogło mieć to zwiazek m.in. $z$ małymi rozmiarami ciała; mniejszym zwierzętom trudniej utrzymać ciepło niż większym, ze względu na mniej ko-

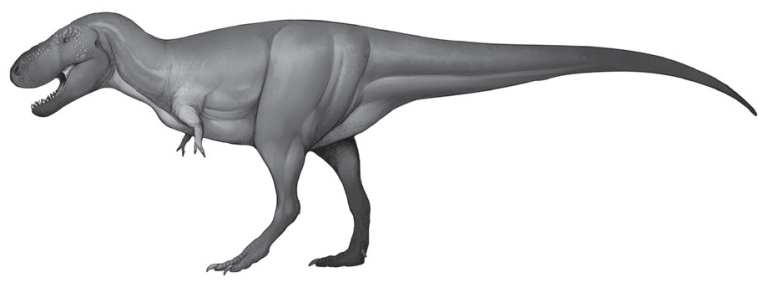

Ryc. 5. Przedstawienie dorosłego osobnika gatunku Tyrannosaurus rex (rys. W. Gornig).

rzystny stosunek objętości ciała do jego powierzchni (MEIRI i DAYAN 2003). W 2012 r. opisano natomiast kolejnego prymitywnego tyranozauroida, tym razem sporo większego. Yutyrannus huali był wczesnokredowym drapieżnikiem mierzącym nawet 9 metrów długości i ważącym około półtorej tony, a zarazem największym znanym opierzonym teropodem (Ryc. 4). Wszystkie znane nauce okazy tego gatunku prezentuja ślady protopiór i sugeruja, że całe zwierze było nimi okryte (XU i współaut. 2012).

$\mathrm{Na}$ podstawie odkryć opierzonych bazalnych tyranozauroidów postawiono dość śmiała tezę, że być może bardziej zaawansowane formy $z$ rodziny tyranozaurydów również mogły mieć ciała okryte mniej lub bardziej zaawansowanymi piórami (XU i współaut. 2012). Najnowsze badania wykazały, że jest ona nieprawdziwa (Ryc. 5). Przeanalizowano odciski skóry zarówno samego $T y$ rannosaurus rex ( $z$ okolic szyi, miednicy $i$ ogona), jak i blisko spokrewnionych $z$ nim rodzajów: Albertosaurus (okolice brzucha i niezidentyfikowanej kończyny), Daspletosaurus, Gorgosaurus (okolice ogona) oraz Tarbosaurus (okolice brzucha). Wszystkie okazy miały skórę pokryta łuskami. Jeżeli pióra występowałyby, musiałyby znajdować się wyłacznie w szczytowych partiach grzbietu (BELl i współaut. 2017). Sama czaszka tyranozaurydów również została zbadana i na podstawie powierzchni kości wykazano, że była pokryta przede wszystkim płaskimi łuskami i rogowymi wytworami w okolicy oczu (CARR i współaut. 2017).

DLACZEGO TYRANOZAUR W TOKU BADAN „ZYSKAE”, A POTEM „STRACIE” PIÓRA?

Wiele wskazuje na to, że u tyranozaurydów pióra uległy wtórnej redukcji. Samo zjawisko redukcji piór nie jest nowościa wśród ptaków. U żyjących współcześnie ptaków paleognatycznych pióra stadiów 4 i 5 uległy redukcji do stadium 3 . U nielotnych papug kakapo pióra na skrzydłach utraciły już swoją asymetryczność (MARTYNIUK 2012). W przypadku współczesnych ptaków reduk- 
cja piór związana jest $z$ nielotnym trybem życia. U tyranozaurów redukcja prymitywnego upierzenia aż do łusek mogła mieć inne implikacje. Warto mieć na uwadze, że większość zaawansowanych późnokredowych tyranozaurydów była olbrzymimi zwierzętami, żyjącymi w goracym klimacie i prowadzacymi aktywny tryb życia. Utrata protopiór mogła pozwalać na bardziej efektywne regulowanie temperatury i zapobiegała przegrzaniu się organizmu (BELL i współaut. 2017).

Znane nauce odciski skóry tyranozaura i jego najbliższych krewniaków nie pozostawiaja wątpliwości, że była pokryta łuskami. Należy jednak postawić pytanie, czy były to łuski homologiczne $z$ łuskami krokodyli. Wiemy, że ptaki również mają łuski; jest to tak zwana podoteka, która pokrywa ptasie nogi od kości goleniowej (lub niżej) po końce palców. Podoteka składa się $z$ dwóch rodzajow łusek: dużych i prostokatnych tarczkowatych i małych siatkowatych (STETTENHEIM 2000).

Przyglądając się ptasim nogom możemy zaobserwować, że stopień pokrycia ich łuskami i piórami różni się w zależności od gatunku (a u ptaków udomowionych nawet $\mathrm{w}$ zależności od rasy). W przypadku np. puchacza śnieżnego (Bubo scandiacus) czy pardwy mszarnej (Lagopus lagopus) stopy sa pokryte piórami niemal całkowicie, łuski wystepuja jedynie na ich spodniej stronie. U nieptasich dinozaurów również można zaobserwować różnorodność w pokryciu dolnych kończyn piórami, przy czym najprymitywniejsze formy sa opierzone aż do palców (ZHENG i współaut. 2013). Eksperymenty wykazały, że zmieniając sekwencje niektórych genów można sprawiać, by pierwotnie opierzone nogi stały się pokryte łuskami, a te $z$ łuskami opierzone, co znaczyłoby, że wykształcanie piór i podoteki ma wspólny mechanizm genetyczny (DHOUAILlY 2009, ZHENG i współaut. 2013). Być może podobne zjawisko występowało także u tyranozaurydów i w rzeczywistości ich łuski sa wtórnie zredukowanymi piórami.

O ile obecne badania dowodzą, że dorosły tyranozaur nie był opierzony, to nie można wykluczyć obecności piór u osobników młodocianych (Ryc. 6) (BELL i współaut. 2017). Okrycie ciała współczesnych ptaków jest dość dynamiczne. Osobniki młodociane często różnią się swoim pokryciem od osobników dorosłych i zdarza się, że w trakcie rozwoju tracą część piór (np. na głowach indyków, kazuarów, sępów). Dinozaury nie stanowiły wyjątku. Jako przykłady można wymienić wspomniane wcześniej Ornithomimus i Similicaudipteryx.

Pisklęta tyranozaura były bardzo małe, a kredowy świat obfitował w zagrożenia. Obec-

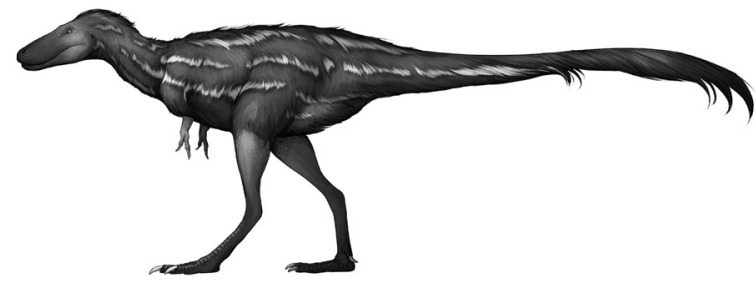

Ryc. 6. Przedstawienie młodocianego przedstawiciela gatunku Tyrannosaurus rex okrytego hipotetycznymi piórami pełniącymi role termoizolacyjne i kamuflażowe (rys. W. Gornig).

ność piór mogłaby nie tylko chronić przed utratą ciepła, ale równiė̇ zapewniać odpowiedni kamuflaż. Tym tropem poszło American Museum of Natural History w Nowym Jorku, które w marcu tego roku otworzyło wystawę, gdzie można podziwiać małe opierzone tyranozaury.

$$
\text { Streszczenie }
$$

Dinozaury sa najbardziej popularnymi mezozoicznymi kręgowcami lądowymi i grupa wyjściową dla ptaków. Wśród szeregu wyróżniających cech ptaki charakteryzują się wyjątkowym okryciem ciała - piórami. Do tej pory pióra wykazano u kilkudziesięciu gatunków nieptasich dinozaurów należących do grupy teropodów. Struktury homologiczne do piór mogły wykształcić się także u dinozaurów ptasiomiednicznych, a nawet u pterozaurów. Żeby to potwierdzić lub wykluczyć, należy kontynuować badania oraz czekać na dalsze odkrycia.

\section{LITERATURA}

BARON M. G., NORMAN D. B., BARRETT P. M., 2017. A new hypothesis of dinosaur relationships and early dinosaur evolution. Nature 543, 501-506.

BARRETT P. M, Evans D. C, CAMPIONE N. E., 2015 Evolution of dinosaur epidermal structures. Biol. Lett. 11, 20150229.

Bell P. R., Campione N. E., Persons W. S., CurRIE P. J., LARSON P. L., TANKE D. H., BAKKER R. T., 2017. Tyrannosauroid integument reveals conflicting patterns of gigantism and feather evolution. Biol. Lett. 13, 20170092.

BENTON M., 2004. Origin and relationships of dinosauria. [W:] The Dinosauria. WeISHAMPEL D. B., DODSON P., OSMÓlskA H. (red.). University of California Press, Berkeley, 7-19.

CARr T., VARricchio D. J., SEDlMayr J. C., RoBERTS E. M., MOORE J. R., 2017. A new tyrannosaur with evidence for anagenesis and crocodile-like facial sensory system. Scient. Rep. 7, 44942.

Chang C., Wu P., Baker R. E., Maini P. K., AliBARDI L., ChUONG C. M., 2009. Reptile scale paradigm: Evo-Devo, pattern formation and regeneration. Int. J. Develop. Biol. 53, 813-826.

ChIAPPE L. M., GÖHLICH U. B., 2010. Anatomy of Juravenator starki (Theropoda: Coelurosauria) from the Late Jurassic of Germany. Neues Jahrbuch Für Geologie Und Paläontologie Abhandlungen 258, 257-296.

CORIA R. A., CHIAPPE L. M., 2007. Embryonic skin from Late Cretaceous sauropods (Dinosauria) 
of Auca Mahuevo, Patagonia, Argentina. J. Paleontol. 81, 1528-1532.

CURRIE P. J., HURUM J. H., SABATH K., 2003. Skull structure and evolution in tyrannosaurid dinosaurs. Acta Palaeontol. Pol. 48, 227-234.

DECECCHI T. A., LARSSON H. C. E., HABIB M. B., 2016. The wings before the bird: an evalu ation of flapping-based locomotory hypotheses in bird antecedents. PeerJ. 4, e2159.

Depalma R. A., Burnham D. A., Martin L. D. LARSON P. L., BAKKER R. T., 2015. The first giant raptor (Theropoda: Dromaeosauridae) from the Hell Creek Formation. Paleontol. Contribut. 14, 1-15.

DHOUAILlY D., 2009. A new scenario for the evolutionary origin of hair, feather, and avian scales. J. Anat. 214, 587-606.

Funston G. F., CURRIE P. J., 2016. A new caenagnathid (Dinosauria: Oviraptorosauria) from the Horseshoe Canyon Formation of Alberta, Cana$\mathrm{da}$, and a reevaluation of the relationships of Caenagnathidae. J. Vertebrate Paleontol. 36, e1160910.

Godefroit P., CAU A., DONG-Yu H., Escuillié F., WENHAO W., DYKE G., 2013. A Jurassic avialan dinosaur from China resolves the early phylogenetic history of birds. Nature 498, 359-362.

Godefroit P., Sinitsa S. M., Dhouailly D., BoLOTSKY Y. L., SizOV A. V., MCNAMARA M. E. BENTON M. J., SPAGNA P., 2014. A Jurassic ornithischian dinosaur from Siberia with both feathers and scales. Science 345, 451-455.

GÖHLICH U. B., CHIAPPE L. M., 2006. A new car nivorous dinosaur from the Late Jurassic Solnhofen archipelago. Nat. Lett. 440, 329-332

HaN G., ChIAPPE L. M., Ji S. A., Habib M., TuRNER A. H., Chinsamy A., LiU X., Han L., 2014. A new raptorial dinosaur with exceptionally long feathering provides insights into dromaeosaurid flight performance. Nat. Comm. 5, $1-9$.

Holtz T. R., 2004. Tyrannosauroidea. [W:] The Dinosauria. WeIshaMPEL D. B.. DODSON P., OSMÓLSKA H. (red.) University of California Press, Berkeley, 111-136.

Ji S., Ji Q., LÜ J., YUAN C., 2007. A New Giant Compsognathid Dinosaur with Long Filamentous Integuments from Lower Cretaceous of Northeastern China. Acta Geol. Sinica 81, 8-15.

LEE Y.N., BARSBOld R., CURRIE P. J., KoBAYASHI Y., LEE H. J., GODEFROIT P., Escuillí F., CHINZORIG T., 2014. Resolving the long-standing enigmas of a giant ornithomimosaur Deinocheirus mirificus. Nature 515, 257-260.

Li Q., GaO K.Q., VinTHER J., SHAWKeY M. D., Clarke J. A., D'Alba L., MENG Q., BRIGGS D. E. G., PRUM R. O., 2010. Plumage color patterns of an extinct dinosaur. Science 327, 1369-1372.

Li Q., GaO K. Q., Meng Q., Clarke J. A., ShaWKey M. D., D’Alba L., PEi R., Ellision M., NoRELL M. A., VINTHER J., 2012. Reconstruction of Microraptor and the Evolution of Iridescent Plumage. Science 335, 1215-1219.

LINGHAM-SOLIAR T., FEDUCCIA A., WANG X., 2007. A new Chinese specimen indicates that "protofeathers' in the Early Cretaceous theropod dinosaur Sinosauropteryx are degraded collagen fibres. Proc. Royal Soc. B, Biol, Sci, 274, 1823-1829.

LiU Y. Q., Kuang H. W., Jiang X. J., PEng N., Xu H., Sun H. Y., 2012. Timing of the earliest known feathered dinosaurs and transitional pterosaurs older than the Jehol Biota. Palaeogeogr. Palaeoclimatol. Palaeoecol. 323, 1-12.
LÜ J., BRUSATTE S. L., 2015. A large, short-armed, winged dromaeosaurid (Dinosauria: Theropoda) from the Early Cretaceous of China and its implications for feather evolution. Scient. Rep. $5,1-11$

MARTYNiUK M., 2012. A Field Guide to Mesozoic Birds and Other Winged Dinosaurs. Pan Aves Vernon, New Jersey.

Mayr G., Peters D., Plodowski G., Vogel O., 2002. Bristle-like integumentary structures at the tail of the horned dinosaur Psittacosaurus. Naturwissenschaften 89, 361-365.

MeIRI S., DAYAN T., 2003. On the validity of Bergmann's rule. J. Biogeogr. 30, 331-351.

Norell M. A., XU X., 2005. Feathered dinosaurs. Ann. Rev. Earth Planet. Sci. 33, 277-299.

O'CONNOR J. K., CHIAPPE L. M., CHUONG C., BOTTJER D. J., YOU H., 2012. Homology and potential cellular and molecular mechanisms for the development of unique feather morphologies in early birds. Geosciences 2, 157-177.

PRUM R., 1999. Development and evolutionary origin of feathers. Journal of Experimental Zoology (Mol Dev Evol) 285, 291-306.

PRUM R. O., BRUSH A., H. 2002. The evolutionary origin and diversification of feathers. Quart. Rev. Biol. 77, 261-295.

Pu H., Kobayashi Y., LÜ J., XU L., WU Y., Chang H., ZHANG J., JiA S., 2013. An unusual basal Therizinosaur dinosaur with an ornithischian dental arrangement from Northeastern China. PLoS One 8, e63423.

RauhuT O. W. M., FOTH C., Tischlinger H., NoRELL M. A., 2012. Exceptionally preserved juvenile megalosauroid theropod $d$ RAUHUT inosaur with filamentous integument from the Late Jurassic of Germany. Proc. Natl. Acad. Sci. USA 109, 11746-11751.

Rauhut O. W. M., Piñuela L. D. Castanera J. C. GarcíA-RAmos I., SÁNCHEZ C., 2018. The lar gest European theropod dinosaurs: remains of a gigantic megalosaurid and giant theropod tracks from the Kimmeridgian of Asturias, Spain. PeerJ. 6, 1-34.

SCHLEE D., 1973. Harzkonservierte fossile Vogelfedern aus der untersten Kreide. J. Ornithol. 114, 207-219.

Schweitzer M. H., Watt J. A., Avci R., KnapP L., Chiappe L., Norell M., Marshall M., 1999. Beta-keratin specific immunological reactivity in feather-like structures of the Cretaceous Alvarezsaurid, Shuvuuia deserti. J. Exp. Zool. 285, 146-157.

STETTENHEIM P. R., 2000. The integumentary morphology of modern birds - an overview. Am. Zool. 40, 461-477.

Sullivan C., Hone D. W. E., Xu X., Zhang F., 2010. The asymmetry of the carpal joint and the evolution of wing folding in maniraptoran theropod dinosaurs. Proc. Royal Soc. B, Biol. Sci. 277, 2027-2033.

TURNer A. H., MAKOVICKY P. J., NOREll M. A., 2017. Feather quill knobs in the dinosaur $\mathrm{Ve}$ lociraptor. Science 317, 17-21.

Vinther J., BRiggs D. E., PRUM R. O., SARANATHAN V., 2008. The colour of fossil feathers. Biol. Lett. 4, 522-525.

WANG M., O'CONNOR J. K., XU X., Zhou Z., 2019. A new Jurassic scansoriopterygid and the loss of membranous wings in theropod dinosaurs. Nature 569, 256-259.

WANG X., ZHOU Z., ZHANG F., XU X., 2002. A nearly completely articulated rhamphorhynchoid pterosaur with exceptionally well-preserved wing membranes and 'hairs' from Inner Mon- 
golia, northeast China. Chinese Sci. Bull. 47, 226-230.

Xing L., Mckellar R. C., Xu X., Li G., Bai M., PERsons W. S., MiYashita T., Benton M. J., Zhang J., Wolfe A. P., Yi Q., Tseng K., RaN H., CURRIE P. J., 2016. A Feathered dinosaur tail with primitive plumage trapped in mid-cretaceous amber. Curr. Biol. 26, 3352-3360.

XU X., GUO Y., 2009. The origin and early evolution of feathers: insights from recent paleontological and neontological data. Vert. PalAsiatica 47, 311-329.

XU X., Wang X. L., Wu X. C., 1999. A dromaeosaurid dinosaur with a filamentous integument from the Yixian Formation of China. Nature 401, 262-266.

XU X., ZHOU Z., WANG X., KuANG X., ZHANG F., DU X., 2003. Four-winged dinosaurs from China. Nature 421, 335-340.

Xu X., NOREll M. A., KuANG X., WANG X., ZHaO Q., JIA C., 2004. Basal tyrannosauroids from China and evidence for protofeathers in tyrannosauroids. Nature 431, 680-684.

XU X., ZHeng X., You H., 2009. A new feather type in a nonavian theropod and the early evolution of feathers. Proc. Natl. Acad. Sci. USA 106, 832-834.

XU X., ZHENG X., YOU H., 2010. Exceptional dinosaur fossils show ontogenetic development of early feathers. Nature 464, 1338-1341.

Xu X., Wang K., Zhang K., Ma Q., XING L., SulLIVAN C., Hu D., Cheng S., WANG S., 2012. A gigantic feathered dinosaur from the Lower Cretaceous of China. Nature 484, 92-95.

Xu X., Zheng X., Sullivan C., Wang X., Xing L., WANG Y., ZHANG X., O'CONNOR J.K., ZHANG F.,
PAN Y., 2015. A bizarre Jurassic maniraptoran theropod with preserved evidence of membranous wings. Nature 521, 70-73.

Xu X., Currie P., Pittman M., Xing L., Meng Q., LÜ J., HU D., YU C.. 2017. Mosaic evolution in an asymmetrically feathered troodontid dinosaur with transitional features. Nat. Comm. $8,14972$.

YANG Z., Jiang B., MCNAMARA M. E., KeARns S. L., Pittiman M., Kaye T. G., OrR P. J., XU X., BENTON M. J., 2018. Pterosaur integumentary structures with complex feather-like branching. Nat. Ecol. Evol. 3, 24-30.

ZELENITSKY D. K., THERRIEN F., ERICKSON G. M., DEBUHR C. L., KoBAYASHI Y., EBERTH D. A., HADFIELD F., 2012. Feathered non-avian dinosaurs from North America provide insight into wing origins. Science 338, 510-514.

Zhang F., ZhOU Z., Xu X., Wang X., Sullivan C., 2008. A bizarre Jurassic maniraptoran from China with elongate ribbon-like feathers. Nature 455, 1105-1108.

Zhang F. C., KeARNS S. L., ORR P. J., Benton M. J., Zhou Z. H., Johnson D., XU X., WANG X., 2010. Fossilized melanosomes and the colour of Cretaceous dinosaurs and birds. Nature 463, 1075-1078.

Zheng X., You H., Xu X., Dong Z., 2009. An Early Cretaceous heterodontosaurid dinosaur with filamentous integumentary structures. Nature 458, 333-336.

ZHENG X., ZHOU Z., WANG X., ZHANG F., ZHANG X., Wang Y., Wei G., WANG S., XU X. 2013. Hind wings in basal birds and the evolution of leg feathers. Science 339, 1309-1312.

KOSMOS Vol. 68, 4, 543-551, 2019

WIKTORIA GORNIG

\begin{abstract}
Department of Evolutionary Biology and Ecology, Department of Paleozoology, 21 Sienkiewicza Str., 50-335 Wrockaw,
\end{abstract}
E-mail: wiktoria.gornig@uwr.edu.pl

\title{
DID TYRANNOSAURUS HAVE WINGS? FEATHERS OF NON-AVIAN DINOSAURS
}

\section{Summary}

Dinosaurs are one of the most recognisable groups of mesosoic vertebrates. Among their characteristics are one of the most unique type of integument - feathers. Feathers has been confirmed in several dozens species of nonavian theropod dinosaurs. Structures potentialy homologous to feathers could also have developed in ornithischian dinosaurs, and even in pterosaurs. In order to confirm or exclude it, one should still wait for further discoveries and research. 